\title{
High temperature properties of modified bituminous binders produced in Poland
}

\author{
Piotr Radziszewski ${ }^{1}$, Michat Sarnowski ${ }^{1}$, Piotr Pokorski ${ }^{1,{ }^{*}}$, Karol J. Kowalski ${ }^{1}$, Jan Król $^{1}$ \\ ${ }^{1}$ Warsaw University of Technology, ul. Lecha Kaczyńskiego 16, 00-637 Warsaw, Poland
}

\begin{abstract}
Bitumen used for the construction of road pavements should exhibit adequate resistance to loads at high operating temperatures. An effective method of improving the properties of bitumen is their modification. To evaluate the high-temperature properties of bitumen, standard consistency tests and advanced rheological tests under dynamic load are conducted. The main purpose of the article is to assess the high temperature properties of modified binders produced by two major Polish producers. The assessment was based on the tests results of modified binders in the range of the standard softening point temperature test and tests in the dynamic shear rheometer (DSR) according to the requirements of Strategic Highway Research Program (SHRP) and Multiple Stress Creep Recovery Test (MSCR). It has been shown that due to the highest operating temperatures of road pavements in Poland, produced bituminous binders meet the requirements of resistance to permanent deformation with a great reserve.
\end{abstract}

\section{Introduction}

Bitumen used for the construction of road pavements should have an appropriate quality that ensures durability of the road construction [1]. The properties of bitumen as viscoelastic materials depend on the temperature and load time and vary from elastic at low temperatures and/or short load to viscous at high temperatures and/or long load times [2, 3]. Bituminous binders characterized by inadequate high temperature properties may contribute to the destruction of the pavement with permanent deformations $[4,5]$. The most frequently used method of improving high-temperature properties of bitumen is their modification with polymers. These binders are commonly used in Poland for road construction that carry a high and very heavy traffic load [6, 7].

To evaluate the viscoelastic properties of bitumen, the standard tests of consistency and cohesion as well as advanced rheological tests are used. One of the better methods of investigating properties at high operating temperatures is the dynamic load test, which allows to determine complex modules $\mathrm{G}^{*}$ and the phase angle $\delta$ between stress and strain. The expression $\mathrm{G}^{*} / \sin \delta$ allows to assess the stiffness of binders in terms of deformability at high temperatures in the summer and to avoid permanent deformation of the pavement at these temperatures or under long-term load, a higher shear modulus $\mathrm{G}^{*}$ and a lower phase angle $\delta$, i.e. binder should have a high proportion of the elastic part [8,9]. The method to evaluate these properties of binders is a test in the dynamic shear rheometer (DSR). According to the Superpave assessment criteria, bitumen with high resistant to the permanent deformation at the highest operating temperatures should meet the requirements $\mathrm{G}^{*} / \sin \delta \geq 1.0 \mathrm{kPa}$ for non-aged asphalt and $\mathrm{G}^{*} / \sin \delta \geq 2.2$ $\mathrm{kPa}$ for short term aged binders by RTFO procedure [3, 9].

For modified bitumen, a better assessment of high temperature properties is a Multiple Stress Creep Recovery Test (MSCR) [10, 11]. The MSCR test is characterized by high temperature properties of bitumen, the effectiveness of bitumen modification with polymers and allows the determination of the maximum functional type of PG [12, 13, 14]. The MSCR test allows to determine the influence of bituminous binders on the resistance of asphalt mixtures to permanent deformation in road pavement [15], depending on the category of traffic load, which is expressed as follows [16]:

- S - standard traffic level, road pavement with a load less than 10 million ESAL (equivalent single axle loads), roads equivalent to traffic categories KR1, KR2, KR3 and partly KR4 may be considered equivalent in Poland, - $\mathrm{H}$ - heavy traffic level, load of the road pavement with traffic from 10 to 30 million ESAL, which corresponds in Poland to the traffic category KR4 - KR5,

- V - very heavy traffic level - traffic load exceeding 30 million ESAL, which corresponds to the KR5 - KR6 traffic category in Poland,

- E - extreme heavy traffic level - traffic load exceeding 30 million ESAL with a standing traffic loading - speed below $20 \mathrm{~km} / \mathrm{h}$, which may correspond to the KR6 KR7 traffic category in Poland.

In 2009-2011, on order for the Polish General Directorate for National Roads and Motorways, the Warsaw University of Technology carried out research on the technical characteristics of road and modified bitumens produced in Poland. On the basis of the results

Corresponding author: p.pokorski@il.pw.edu.pl 
of the research a high variation in the properties of binders was found, both in individual types of binders as well as in producer groups. Part of the tested modified binders was characterized by a non-homogeneous phase of polymer dispersion in microstructure research and unfavourable elastic properties (the value of resilience below 50\%) [3]. In the questionnaire survey carried out as part of the research project RID - Development of Road Innovation "Road asphalts and modified in Polish climatic conditions", road works contractors and investors also pointed to problems related to the quality of polymer modified binders produced [17].

\section{Objective and scope of research}

The main purpose of the work presented in this paper was to assess the properties of high temperature modified bitumens produced by two major Polish producers. The evaluation was based on the results of tests of modified binders in the range of the standard softening point temperature by $\mathrm{R} \& \mathrm{~B}$ method and the tests under dynamic load in the DSR dynamic shear rheometer according to the requirements of SHRP and MSCR.

\section{Tested materials and methodology}

The research plan covered the following types of modified bitumens produced in Poland: PMB 10/40-65, PMB 25/55-60, PMB 45/80-55, PMB 45/80-65, PMB 25/55-60CR, PMB 45/80-55CR. The last two binders (with the CR symbol - crumb rubber) are terminal blend bitumen modified both by crumb rubber and SBS polymer.

The softening point temperature of modified bitumen was determined in accordance with PN-EN 1427. The DSR test performed in accordance with the PN-EN 14770 standard defines a complex $G^{*}$ modulus and phase angle $\delta$ between stress and the strain. The viscoelastic properties of the binder were tested under a sinusoidal (cyclic) load at various temperatures from 10 ${ }^{\circ} \mathrm{C}$ to $94{ }^{\circ} \mathrm{C}$. Two types of samples of the same binders were tested, i.e. original binder and aging binder according to RTFO. The weight of the test sample was 1 $\mathrm{g}$, the angular velocity $10 \mathrm{rad} \mathrm{s}=1.59 \mathrm{~Hz}$. The diameter of the plate $\phi$ and the thickness of the adhesive layer $\mathrm{d}$ is for the original binders and binders after aging RTFOT equal to: $\phi 25 \mathrm{~mm}, \mathrm{~d}=1.00 \mathrm{~mm}$. The MSCR test was performed in a dynamic shear (DSR) rheometer according to the AASHTO TP70 standard procedure (parallel plates with a diameter of $25 \mathrm{~mm}, 1 \mathrm{~mm}$ gap). At $64{ }^{\circ} \mathrm{C}$, adopted as the highest seven-day average by type of functional PG in Poland, samples of asphalt binders after RTFO short-term aging were subjected to a repeated constant load of $0.1 \mathrm{kPa}$ and $3.2 \mathrm{kPa}$ in 1 second and then after each load cycle the material was relaxed during 9 seconds. A single cycle lasted 10 seconds and was repeated ten times.

The multiple stress creep recovery (MSCR) test determined the percentage average elastic recovery $R$ and the non-recoverable creep compliance Jnr, which were calculated according to formulas 1,2 and 3

$$
\begin{gathered}
\mathrm{R}=\sum \varepsilon \operatorname{ri}(\tau, \mathrm{N}) / 10 \\
\operatorname{Jnr}=\sum \operatorname{Jnr}(\tau, \mathrm{N}) / 10 \\
\operatorname{Jnri}=\varepsilon_{10 \mathrm{i}} / \tau
\end{gathered}
$$

In those formulas the following symbols are used :

$\tau$ - stress,

$\mathrm{N}$ - number of cycles,

$\varepsilon$ ri $=(\varepsilon 1 \mathrm{i}-\varepsilon 10 \mathrm{i}) * 100 / \varepsilon 1 \mathrm{i}-$ relative strain increment after the one cycle

E1i - strain increment after the first second cycle (at the end of the phase of creep)

$\varepsilon 10 \mathrm{i}$ - strain increment after the 10 second cycle (at the end of the relaxation phase).

In order to evaluate the resistance to permanent deformation of bituminous binders according to AASHTO MP 19-10, the requirement for the percentage difference of the non-recoverable creep compliance part of the Jnr,diff calculated baseds on the Jnr test results at a stress of $3.2 \mathrm{kPa}$ and $0.1 \mathrm{kPa}(4)$ was also included.

$$
\mathrm{Jnr}, \text { diff }=(\mathrm{Jnn} 3,2-\mathrm{Jnr} 0,1) * 100 / \mathrm{Jnr} 0,1
$$

In this formula the following symbols are used :

Jnr0,1 - nonrecoverable creep compliance at $0,1 \mathrm{kPa}$ stress level,

Jnr3,2 - nonrecoverable creep compliance at 3,2 $\mathrm{kPa}$ stress level.

According to the AASHTO MP 19-10 standard, the content of polymer in modified asphalt was evaluated (Fig. 1) [13]. Figure 1 shows the dependence of the percentage average elastic recovery $\mathrm{R}$ on nonrocoverable creep compliance Jnr, a curve with the equation $\mathrm{R}=29.371 \cdot \mathrm{Jnn}^{-0.2633}$ was applied. Bituminous binders whose percentage average elastic recovery at 3.2 $\mathrm{kPa}$ will assume values from the set above the curve, contain the appropriate amount of polymer and characterize the modified binder. Whereas bitumens, whose percentage average elastic recovery assumes values from the set below the curve, characterize unmodified or polymer modified binders in insufficient quantity. 


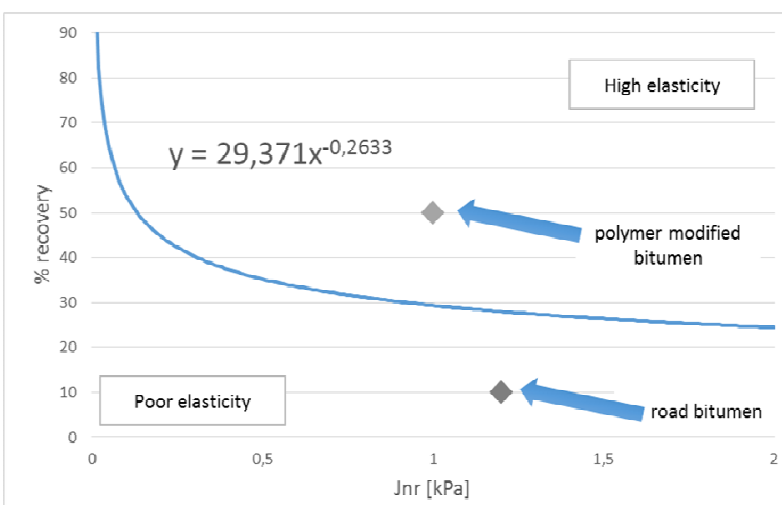

Fig. 1. Example of relationship between percentage average elastic recovery $\mathrm{R}$ and the Jnr parameter used to check the effectiveness of polymer modification

\section{Results and analysis}

The results of the softening point temperature by $\mathrm{R} \& \mathrm{~B}$ method for binders before aging and after RTFO aging are shown in Table 1.

Table 1. Change in softening point temperature after RTFO aging for binders from two different producers

\begin{tabular}{|c|c|c|c|}
\hline $\begin{array}{c}\text { Binder type_ } \\
\text { Producer } \\
\text { number }\end{array}$ & $\begin{array}{c}\text { Softening } \\
\text { point } \\
\text { R\&B }\left[{ }^{\circ} \mathrm{C}\right]\end{array}$ & $\begin{array}{c}\text { Softening } \\
\text { point } \\
\text { R\&B after } \\
\text { RTFO }\left[{ }^{\circ} \mathrm{C}\right]\end{array}$ & $\begin{array}{c}\text { Change } \\
\text { softening } \\
\text { point } \\
\text { R\&B after } \\
\text { RTFO }\left[{ }^{\circ} \mathrm{C}\right]\end{array}$ \\
\hline $\begin{array}{c}\text { PMB } \\
\text { 10/40-65_1 }\end{array}$ & 65 & 72 & 7,0 \\
\hline $\begin{array}{c}\text { PMB } \\
\text { 10/40-65_2 }\end{array}$ & 72 & 77 & 5,0 \\
\hline $\begin{array}{c}\text { PMB } \\
\text { 25/55-60_1 }\end{array}$ & 69,5 & 77,5 & 8,0 \\
\hline $\begin{array}{c}\text { PMB } \\
25 / 55-60 \_2\end{array}$ & 65 & 72 & 7,0 \\
\hline $\begin{array}{c}\text { PMB } \\
\text { 45/80-55_1 }\end{array}$ & 67,5 & 71,5 & 4,0 \\
\hline $\begin{array}{c}\text { PMB } \\
45 / 80-55 \_2\end{array}$ & 60 & 66,5 & 6,5 \\
\hline $\begin{array}{c}\text { PMB } \\
45 / 80-65 \_1\end{array}$ & 70 & 70,1 & 0,1 \\
\hline $\begin{array}{c}\text { PMB } \\
45 / 80-65 \_2\end{array}$ & 77,5 & 80,7 & 3,6 \\
\hline $\begin{array}{c}\text { PMB } \\
25 / 55-60 \\
\text { CR_1 }\end{array}$ & 63,2 & 70,6 & 7,4 \\
\hline $\begin{array}{c}\text { PMB } \\
45 / 80-55 \\
\text { CR_1 }\end{array}$ & 62,5 & 70,5 & 8,0 \\
\hline
\end{tabular}

It can be noticed that in groups of hardness of modified bitumens there is a high variation in the results of the tests of binders, both before and after aging, ranging from $5^{\circ} \mathrm{C}$ to $10^{\circ} \mathrm{C}$. It should also be stated that modified bitumens meet the standard requirements in terms of softening point temperature.

The determination of the complex modulus $\mathrm{G}^{*}$ and the phase shift angle $\delta$ between stress and strain as a function of temperature is a good assessment of the viscoelastic properties of the bituminous binders. The value of phase angle $\delta$ close to $0^{\circ} \mathrm{C}$ indicates the total stiffening of the binder, which leads to fracture toughness temperature. At high operating temperatures due to the possibility of liquefaction of the binder, the phase shift angle should not reach $90^{\circ} \mathrm{C}$.

The results of the complex module $\delta$ and the phase angle tests are presented on Fig. 2. and Fig. 3.

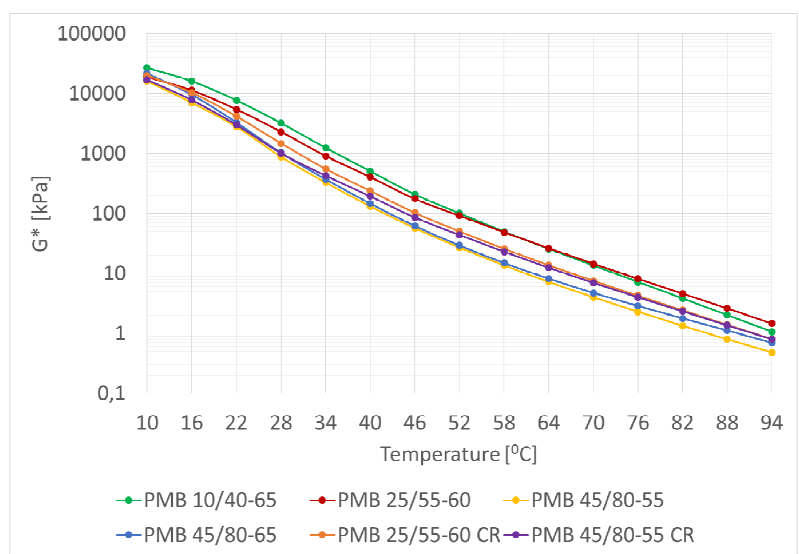

Fig. 2. Dynamic modulus $G^{*}$ as a function of temperature

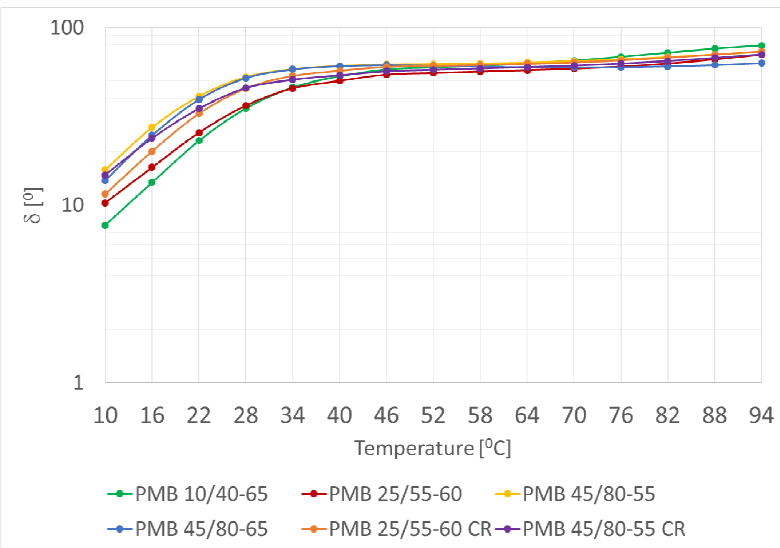

Fig. 3. Phase angle as a function of temperature

Fig. 2. shows that the binder modified at high test temperatures shows relatively high values of $\mathrm{G}^{*}$ modules and lower values of the phase angle $\delta$. It can be predict that the modified binder will exhibit high resistance to permanent deformation in the road pavement. Among the asphalt binders for distinguishing, in terms of properties at high temperatures, the PMB 25/50-60 modified binder, which at these temperatures has higher values of the complex modulus and lower phase angle, what results in higher resistance to permanent deformation. The worst high temperature properties of binders are exhibited by PMB 45/80-55.

On the basis of the analysis of the results it should be stated that the change in the complex modulus as a function of temperature of the modified PMB 45/80-55 $\mathrm{CR}$ binder should be positively distinguished (higher $\mathrm{G}^{*}$ values at high temperatures and lower values of $\delta$ at lower temperatures). Considering the results of the phase 
shift test in this group of binders, attention should be paid to the beneficial behaviour of modified binders, including PMB 45/80-65 and PMB 45/80-55 CR. Those binders maintain elastic properties at the highest operating temperatures (smaller phase angle).

The results of the MSCR test, i.e. the percentage average elastic recovery $\mathrm{R}$ and the non-recoverable creep compliance Jnr are presented in the table 2 and in fig. 4 and fig 5 .

Table 2. Results of percentage average elastic recovery $\mathrm{R}$ and the modulus of compliance Jnr for polymer modified bitumen and terminal blend binders at $64^{\circ} \mathrm{C}$ temperature

\begin{tabular}{|c|c|c|c|c|c|}
\hline $\begin{array}{c}\text { Binder } \\
\text { type }\end{array}$ & $\begin{array}{c}\text { R0.1 } \\
{[\%]}\end{array}$ & $\begin{array}{c}\mathrm{Jnn}^{2} 0.1 \\
{\left[\mathrm{kPa}^{-1}\right]}\end{array}$ & $\begin{array}{c}\mathrm{R} 3.2 \\
{[\%]}\end{array}$ & $\begin{array}{c}\text { Jnr3.2 } \\
{\left[\mathrm{kPa}^{-1}\right]}\end{array}$ & $\begin{array}{c}\text { Jnr,diff } \\
{[\%]}\end{array}$ \\
\hline $\begin{array}{c}\text { PMB } \\
10 / 40-65\end{array}$ & 35,97 & 0,23 & 29,21 & 0,26 & 14,51 \\
\hline $\begin{array}{c}\text { PMB } \\
10 / 40-65 \\
\text { RTFOT }\end{array}$ & 56,66 & 0,06 & 54,38 & 0,07 & 6,34 \\
\hline $\begin{array}{c}\text { PMB } \\
25 / 55-60\end{array}$ & 71,08 & 0,07 & 68,88 & 0,08 & 7,61 \\
\hline $\begin{array}{c}\text { PMB } \\
25 / 55-60 \\
\text { RTFOT }\end{array}$ & 80,78 & 0,02 & 78,28 & 0,02 & 13,41 \\
\hline $\begin{array}{c}\text { PMB } \\
45 / 80-55\end{array}$ & 64,17 & 0,41 & 56,40 & 0,50 & 21,13 \\
\hline $\begin{array}{c}\text { PMB } \\
45 / 80-55 \\
\text { RTFOT }\end{array}$ & 71,06 & 0,14 & 70,11 & 0,15 & 3,09 \\
\hline $\begin{array}{c}\text { PMB } \\
45 / 80-65\end{array}$ & 87,64 & 0,09 & 86,34 & 0,10 & 5,96 \\
\hline $\begin{array}{c}\text { PMB } \\
45 / 80-65 \\
\text { RTFOT }\end{array}$ & 90,75 & 0,04 & 87,79 & 0,05 & 31,46 \\
\hline $\begin{array}{c}\text { PMB } \\
25 / 55-60 \\
\text { CR }\end{array}$ & 61,39 & 0,14 & 56,47 & 0,15 & 14,48 \\
\hline $\begin{array}{c}\text { PMB } \\
25 / 55-60 \\
\text { CR } \\
\text { RTFOT }\end{array}$ & 70,62 & 0,08 & 68,95 & 0,08 & 7,71 \\
\hline $\begin{array}{c}\text { PMB } \\
45 / 80-55 \\
\text { CR }\end{array}$ & 68,52 & 0,16 & 60,90 & 0,21 & 31,94 \\
\hline $\begin{array}{c}\text { PMB } \\
45 / 80-55 \\
\text { CR } \\
\text { RTFOT }\end{array}$ & 77,51 & 0,06 & 75,87 & 0,07 & 9,45 \\
\hline
\end{tabular}

The table 3. shows the requirements for resistance to permanent deformation of bituminous binders determined based on the MSCR test.

Table 3. Requirements for resistance to permanent deformation of bituminous binders according to AASHTO MP 19-10

\begin{tabular}{|c|c|c|c|}
\hline \multicolumn{4}{|c|}{ Traffic load } \\
\hline Standard S & Heavy H & Very heavyV & Extreme E \\
\hline $\begin{array}{c}\mathrm{J}_{\mathrm{nr} 3,2} \leq 4.0 \\
\mathrm{kPa}^{-1}\end{array}$ & $\begin{array}{c}\mathrm{J}_{\mathrm{nr} 3,2} \leq 2.0 \\
\mathrm{kPa}^{-1}\end{array}$ & $\begin{array}{c}\mathrm{J}_{\mathrm{nr} 3,2} \leq 1.0 \\
\mathrm{kPa}^{-1}\end{array}$ & $\begin{array}{c}\mathrm{J}_{\mathrm{nr} 3,2} \leq 0,5 \\
\mathrm{kPa}^{-1}\end{array}$ \\
\hline $\mathrm{J}_{\text {nrdiff }} \leq 75 \%$ & $\mathrm{~J}_{\text {nrdiff }} \leq 75 \%$ & $\mathrm{~J}_{\text {nrdiff }} \leq 75 \%$ & $\mathrm{~J}_{\text {nrdiff }} \leq 75 \%$ \\
\hline
\end{tabular}

Generally, it can be stated that the percentage average elastic recovery $\mathrm{R}$ determines the elastic properties of the binder, whereas the non-recoverable creep compliance Jnr is characterized by the binder's susceptibility to the formation of permanent deformations. The higher value of the no recoverable creep compliance results in lower resistance to permanent deformation. Requiring a percentage difference of the no recoverable creep compliance part Jnr,diff expresses the binder's sensitivity to load change (it is recommended that it is not greater than $75 \%$ ), and the lower Jnr,diff value in the MSCR test is beneficial.

Based on the results of the tests given in the table 2 , in terms of elastic properties ( $\mathrm{R})$, the tested binders can be classified in the following groups from more to less resistant on permanent deformation:

- binder exhibits very high resilience, $\mathrm{R}>85 \%$ : PMB 45/80-65,

- binders exhibit high elasticity, R> 75\%: PMB 25/5560, PMB 45/80-55 CR,

- binders exhibit medium-high elasticity, R> 65\%: PMB 25/55-60 CR, PMB 45/80-55,

- binders exhibit semi elasticity, R> 50\%: PMB 10/4065 .

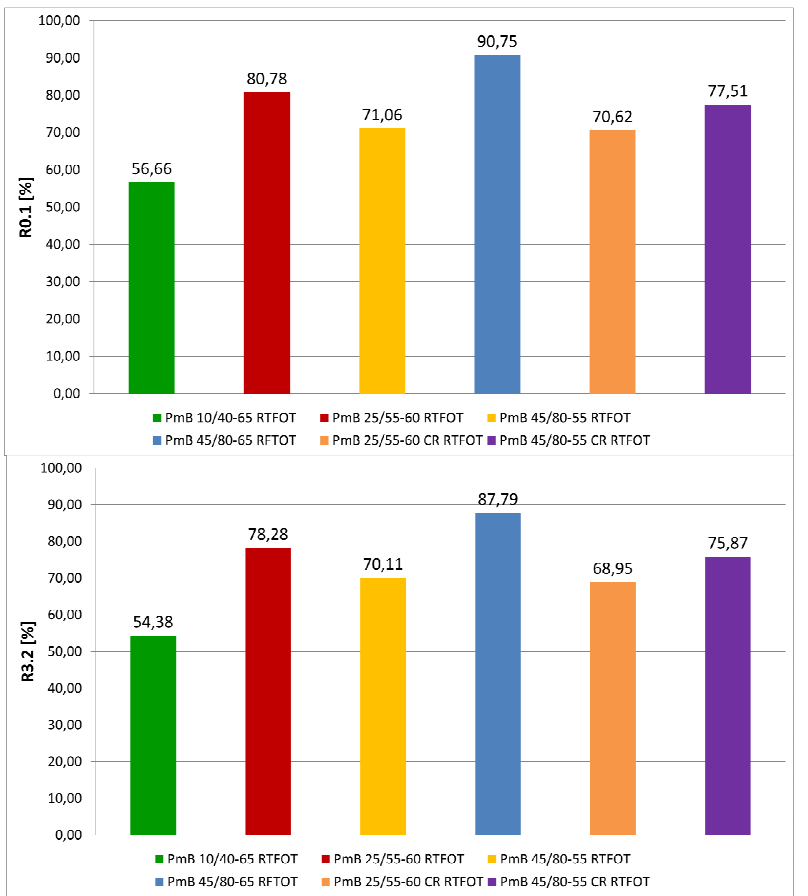

Fig. 4. Elastic recovery $\mathrm{R}$ at $0,1 \mathrm{kPa}$ and $3,2 \mathrm{kPa}$ stress level for modified bitumens 


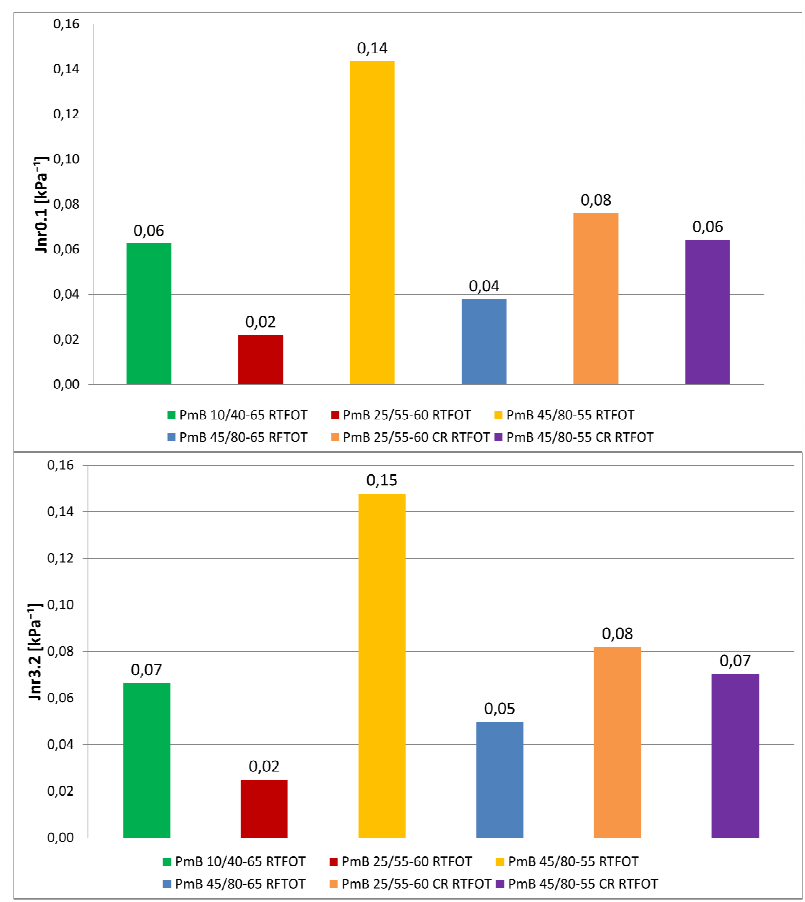

Fig. 5. No recoverable creep compliance Jnr at $0,1 \mathrm{kPa}$ and 3,2 $\mathrm{kPa}$ stress level for modified bitumens

On the basis of the no recoverable creep compliance Jnr analysis (table 2.) it should be stated that all tested binders shown very low values of the Jnr modulus (less than $0,5 \mathrm{kPa}^{-1}$ ). Among these binders, the highest susceptibility to accumulating permanent deformations exhibits PMB 45/80-55 binder. On the other hand, the highest resistance to permanent deformations among the tested modified binders is characterized by PMB 25/55-60, previously included in the group with high elasticity. Similarly, the PMB 45/8065 binder $(J n r 3.2=0.05 \mathrm{kPa}-1)$, which showed the highest elasticity among the modified bitumen tested, should be highly evaluated in terms of resistance to deformation. Binder PMB 25/55-60 CR, PMB 45/80-55 CR and PMB 10/40-65 can be classified as modified binders with medium resistance to permanent deformation of modified binders. When comparing Jnr test results at $3.2 \mathrm{kPa}-1$ with AASHTO MP 19-10 requirements, all tested binder should be qualified for resistance to permanent deformation as useful for road surfaces for class $\mathrm{E}$ of extreme traffic loads.

Fig. 6. presents a graphical classification of the tested binders on the basis of the percentage average elastic recovery $\mathrm{R}$ in function of no recoverable creep compliance Jnr. Fig. 6. shows that all modified bitumens, in addition to the PMB 10/40-65 binder, have a sufficient elastomer content. Percent elastic deformation for the PMB 10/40-65 binder is below the curve determined by the formula $\mathrm{y}=29.371 \mathrm{x}^{-0.2633}$ and therefore the binder should be classified as modified bitumen with insufficient elastomer content.

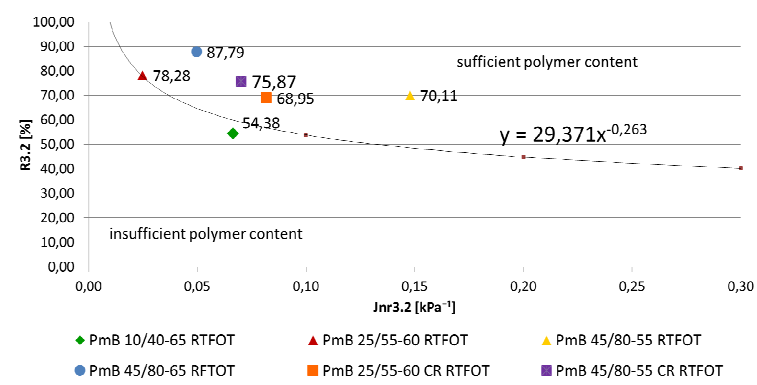

Fig. 6. Results of percentage average elastic recovery $R$ as a function of Jnr parameter at 3,2 kPa stress level for modified bitumens

\section{Conclusions}

Based on the conducted tests and analysis of the polymer modified bitumen, the following conclusions can be drawn:

1. In Poland, binders are produced of various hardness as modified with SBS polymer and modified both by polymer and rubber additives. Tested binders have been characterized by appropriate properties in the range of softening point temperature assessment, both before and after short-term aging.

2. Viscoelastic properties of modified binders, determined by the complex modulus and the phase angle, indicate high resistance of these binders to permanent deformation.

3. According to the MSCR evaluation, all tested modified binders should be qualified in terms of resistance to permanent deformation as useful for road pavements for E category of extremely high traffic.

4. In terms of the highest operating temperatures of road pavements in Poland, produced bituminous binders meet the requirements of resistance to permanent deformation with a great reserve.

\section{Funding}

This work was supported by the Polish General Directorate for National Roads and Motorways and the National Centre of Research and Development [grant number DZP/RID-I-25/2/NCBR/2016].

\section{References}

1. P. Radziszewski, J. Nazarko, T. Vilutiene, K. Dębkowska, J.Ejdys, A.Gudanowska, K. Halicka, J. Kilon, A.Kononiuk, K. Kowalski, J. Król, Ł. Nazarko, M. Sarnowski, Future trends in road pavement technologies development in the context of environmental protection. The Baltic Journal of Road and Bridge Engineering Volume 11(2) (2016), $160-168$ 
2. J. Piłat, P. Radziszewski, Nawierzchnie asfaltowe. Wydawnictwa Komunikacji i Łączności, Warszawa (2010)

3. P. Radziszewski, K. Kowalski, J. Król, M. Sarnowski, J. Piłat, Quality assessment of bituminous binder based on the viscoelastic properties: Polish experience. Journal of Civil Engineering and Management, Volume 20 (1), Taylor \& Francis Group (2014), 111 - 120

4. P. Radziszewski, Modified Asphalt Mixtures Resistance to Permanent Deformation. Journal of Civil Engineering and Management, Lithuanian Academy of Sciences, Vol XIII, No 4, Vilnius (2007), 307-315

5. J.B. Sousa, , J. Craus, \& C.L. Monismith, Summary report on permanent deformation in asphalt concrete. Washington, D.C., SHRP (1991)

6. P. Radziszewski, Wpływ modyfikacji elastomerem SBS na wtaściwości reologiczne lepiszczy asfaltowych. Polimery, Tom LIII, nr 7/8, 55-59, Warszawa (2008)

7. J. Król, P. Czajkowski, P. Radziszewski, K. Kowalski, M. Sarnowski, Laboratory and field investigations of polymer and crumb rubber modified bitumen, Journal of Civil Engineering and Architecture (2014) vol. 8(10), pp. 1327-1334

8. The Shell Bitumen Handbook. Shell Bitumen. Great Britain (1990)

9. T.W. Kennedy, G.A. Huber, The SUPERPAVE System. Strasse u. Verkehr 6 (1994), nr 6

10. J. Zhang, L.F. Walubita, A.N.M. Faruk, P. Karki, G.S. Simate, Use of the MSCR test to characterize the asphalt binder properties relative to HMA rutting performance - A laboratory study. Construction and Building Materials 94 (2015) 218227 ,

http://dx.doi.org/10.1016/j.conbuildmat.2015.06.044

11. X. Yang, Z. You, High temperature performance evaluation of bio-oil modified asphalt binders using the DSR and MSCR tests. Construction and Building Materials $\quad 76 \quad$ (2015), 380-387, http://dx.doi.org/10.1016/j.conbuildmat.2014.11.063

12. J. B. Król, P. Radziszewski, K. J. Kowalski, M. Sarnowski, Assessment of an appropriate modifier content in modified bitumen based on the multiple stress creep recovery test. Edited by: Lakusic, S. Conference: 3rd International Conference on Road and Rail Infrastructure (CETRA) Location: Split, CROATIA Date: APR 28-30, (2014), ROAD AND RAIL INFRASTRUCTURE III Book Series: Road and Rail Infrastructure, pp. 431-437

13. J. Król, P. Radziszewski, K. Kowalski, Influence of microstructure behavior on multiple stress creep recovery (MSCR) in modified bitumen. XXIV R-S-P seminar, Theoretical Foundation of Civil Engineering, Procedia Engineering 111 (2015), 478 - $484 \quad$ (ELSEVIER) DOI: 10.1016/j.proeng.2015.07.119
14. J. D’Angelo, R. Kluttz, R. Dongre, K. Stephens, L. Zanzotto, Revision of the Superpave high temperature binder specification: the multiple stress creep recovery test. Assotiation of Asphalt Paving Technologists Proceedings of the technical sessions 76 (2007), 293-331

15. E. DuBois, Y. Mehta, A. Nolan, Correlation between multiple stress creep recovery (MSCR) results and polymer modification of binder. Construction and Building Materials 65 (2014), 184-190, http://dx.doi.org/10.1016/j.conbuildmat.2014.04.111

16. The multiple stress creep recovery (MSCR) procedure. U.S. Department of Transportation Federal Highway Administration. Office of Pavement Technology FHWA-HIF-11-038 (April 2011)

17. P. Radziszewski, P. Pokorski, A. Gudanowska, Ocena lepiszczy asfaltowych stosowanych do nawierzchni drogowych w Polsce - badania ankietowe. Magazyn Autostrady, ELAMED E. i R. Cholewa Spółka Jawna, nr 10 (2017), 22-27 